\title{
Journal of Biodiversity, Bioprospecting and Development
}

\section{Seasonal Distributions of True Frogs (Family Ranidae) in Tropical Rainforest of Southwestern Nigeria}

\author{
Ajibola ME ${ }^{1}$, Akinpelu $\mathrm{Al}^{1}$ and Imeh-Nathaniel $\mathrm{A}^{2^{*}}$ \\ ${ }^{1}$ Zoology Department, Obafemi Awolowo University, Ile-Ife, Osun State, Nigeria \\ ${ }^{2}$ Department of Biology, North Greenville University, Tigerville, South Carolina, USA
}

"Corresponding author: Adebobola Imeh-Nathaniel, Department of Biology, College of Science and Mathematics, North Greenville University, $7801 \mathrm{~N}$ Tigerville Rd. Tigerville, SC 29866, USA, Tel: (864)4559846; Fax: (864)4558404; E-mail: Adebobola.nathaniel@ngu.edu

Received date: Oct 20, 2014, Accepted date: Nov 27, 2014, Publication date: Dec 03, 2014

Copyright: $\odot 2014$ Ajibola ME, et al. This is an open-access article distributed under the terms of the Creative Commons Attribution License, which permits unrestricted use, distribution, and reproduction in any medium, provided the original author and source are credited.

\begin{abstract}
Although Nigeria encompasses one of the most abundant anuran faunas in the world, quantitative information on anuran ecology are limited, especially in the Southwestern region. Four study sites with different vegetation structures in southwest Nigeria were selected and monitored for anuran species. Four species (Rana asdpersa, $R$. aurora, $R$. clamitans and $R$. sylvatica) of the family Ranidae were identified. The study sites were located at Okitipupa, Ore, Osogbo and lle-lfe. This study was carried in both rainy and dry season, between the years 2002 and 2007. In general, fewer number of amphibian species were observed during the dry season at the four study sites. Total number of individuals caught in the study sight was slightly higher in the rainy season $(53.4 \%)$ than in the dry season $(46.6 \%)$. In each of the seasons, more of $R$. clamitans and $R$. sylvatica were captured than $R$. aurora and $R$. adspersa; with $R$. aurora accounting for the least number of frog species caught in both dry and rainy seasons. Habitat destruction and modification are key causes of habitat loss of anuran species observed in this study. Focus should be on conservation strategies that monitor and detect changes (increase/decrease) in the diversity and abundance of the ranids and other anurans within a specified study area of interest over time.
\end{abstract}

Keywords: Abundance; Distribution; Decline; Conservation; Seasons

\section{Introduction}

Recent studies have indicated the alarming rate at which anuran species are declining and disappearing. Out of the estimated 5918 known species of anurans, an estimated 1856 species are listed as endangered on the International Union for the Conservation of Nature (IUCN) endangered species list [1]. Of the 32 families under the order Anura, the family Ranidae is represented by 54 genera with 772 species [2]. Amphibians including the ranids are of tremendous ecologically significance as indicator species. In other words, their presence or absence in a particular ecosystem may be used in determining the health of such ecosystem [3]. Apart from this, amphibians are secondary consumers in the food chain and have significant roles in the nutritional cycling in the ecosystem.

In general, the population of amphibian species and individuals has declined in recent years primarily because most species no longer have as much of their requisite habitat as they did a century ago. Manmade activities including environmental pollution, global changes and other activities have been proposed to constitute to the widespread amphibian declines [4-7]. Several lines of evidence indicate that human activities have contributed mostly to loss of biodiversity. This can be seen in the clearing or burning of the forest as well as water pollution that serves as the abode for the greatest diversity of anurans [8]. For 7 out of every 10 amphibian species that are classified as threatened, habitat loss is a key threat [9]. This habitat loss is primarily caused by expanding agriculture, road building, dam construction and housing developments.
Acknowledging the significance of amphibians in our environment and the fast and extraordinary rate of their decline [10-12], requires the need for its conservation. Amphibians are major components of both aquatic and terrestrial communities, manmade activities that negatively affect them may, influence the entire ecosystem [3]. It is important to protect and maintain high quality ecosystems both in the terrestrial as well as aquatic ecosystems. For this reason, the need to create protected areas and conservation sites with optimal thriving conditions for amphibian species must be a priority.

The frog family Ranidae (sensu [2], equivalent to Raninae sensu [13] contains over 300 species and have been recorded in many temperate and tropical parts of the world [14] but not well documented in western Africa tropical rainforest areas. They are described as having streamlined, bullet-shaped bodies and pointed heads. There are protruding eyes; on most species of this family, while the fingers are free, but the toes are webbed [15]. They possess welldeveloped legs that allow them to make phenomenal leaps when escaping from their predators. We focused on the family Ranidae (also known as the true frogs) because they display tremendous ecological, morphological, and developmental diversity across a wide geographical range. The true frogs vary greatly in size, ranging from small, such as the Wood frog (Rana sylvatica), to the largest frog in the world, the Goliath frog (Conraua goliath). They have been widely reported all over North America, Central America, in the northern part of South America, in all of Europe, Asia and Africa with the exception of frozen or desert areas, and in northern Australia. However, little information exists about their distributions and seasonal variations in Nigeria.

The current study determines the occurrence and abundance of four species (Rana asdpersa, $R$. aurora, $R$. clamitans and $R$. sylvatica) 
of the family Ranidae within selected vegetation sites of southwest Nigeria. The data generated in this study will provide base-line information to help develop conservation plans to protect and improve this ecologically important biological diversity.

\section{Materials and Methods}

\section{Study Species}

Four species of the family Ranidae -Rana asdpersa, $R$. aurora, $R$. clamitans and $R$. sylvatica were used during this study. From field observation, Rana asdpersa have very broad head, interrupted skin ridges on the back and may vary from brown to grey in color. Rana aurora has smooth skin, red $\neg$ legged as adult with facial masks with single characteristic light stripes along jawlines and they also have long powerful legs. Rana clamitans are heavy bodied frogs with distinct fold of skin that extends from the eyes around the posterior edge of the tympanum to the shoulder. They have two distinct ridges of skin (dorsolateral folds) present on the dorsal side of the body. Rana sylvatica are light brown frogs with prominent dark masks ending behind the eardrums. They have light stripes on the upper jaw and dorsolateral ridges are prominent.

\section{Study Area}

The study area include Ore in Odigbo Local Government Area and Okitipupa in Okitipupa Local Government Area of Ondo State; Osogbo and the Oxidation pond at Obafemi Awolowo University, IleIfe, Osun State, all in Nigeria. Ore is located in North East of Okitipupa and is about $250 \mathrm{~m}$ above sea level with an undulating land surface. Ore falls into a forest region of uneven age forest with an annual rainfall of approximately $1600 \mathrm{~mm}$. The length of the rainy season is usually 8 months (March-October inclusive) and ending in November. The mean humidity is $80 \%$ while the mean annual maximum temperature is $31^{\circ} \mathrm{C}$ and the mean annual minimum is $22^{\circ} \mathrm{C}$. Ore falls along Latitudes $06^{\circ} 43^{\prime}$ and $06^{\circ} 47^{\prime}$ North of the equator and Longitudes $004^{\circ} 51^{\prime}$ and $004^{\circ} 55^{\prime}$ East of the Meridian.

Okitipupa is located in the South of Ondo in the South Western part of Nigeria between Latitudes $06^{\circ} 0^{\prime} \mathrm{N}$ and $06^{\circ} 7^{\prime} \mathrm{N}$ of the equator and Longitudes $00405^{\prime} \mathrm{E}$ and $004^{\circ} 11^{\prime} \mathrm{E}$ of the Greenwich Meridian. It covers an area of about $1800 \mathrm{~km}^{2}$ [16]. It lies in a tropical forest zone with high rainfall of about $1,900 \mathrm{~mm}$ annually spreading through March to November. It also has the characteristic double maxima rainfall. The August break is particularly marked in the area [17].

Osogbo, North West of Ilesa is the capital city of Osun State, Nigeria. It is about $50 \mathrm{~km}$ North East of Ile-Ife town. The altitude is $500 \mathrm{~m}$ above sea level and the vegetation is a deciduous forest [18] intermingled with tall grasses. The annual rainfall is $1000-1400 \mathrm{~mm}$ [19]. The grid reference of Osogbo is along latitudes $07^{\circ} 48^{\prime}$ North and $07^{\circ} 56^{\prime}$ North of the equator and Longitudes $004^{\circ} 30^{\prime} \mathrm{E}$ and $004^{\circ} 37^{\prime}$ East of the Greenwich Meridian.

Oxidation pond, Obafemi Awolowo University (OAU) is located at the outskirts of Ile-Ife covering an area of about $56 \mathrm{~km}^{2}$ with a small percentage of less than $10 \%$ presently built us as the central campus. Ile-Ife lies between longitudes $004025^{\prime} \mathrm{E}$ and $004^{\circ} 32^{\prime} \mathrm{E}$ of the Greenwich Meridian and Latitudes $07^{\circ} 22^{\prime} \mathrm{N}$ and $07^{\circ} 28^{\prime} \mathrm{N}$ of the equator. The main campus of O.A.U., Ile-Ife, Nigeria on the North Western outskirts of Ile-Ife, $220 \mathrm{~km}$ North East of Lagos, Nigeria covers about 5,605 hectares and is at altitude $300 \mathrm{~m} \mathrm{[20].} \mathrm{The} \mathrm{area}$ occupied by the campus lies within the tropical lowland moist forest zone of Southern Nigeria [21] cited by Akinpelu [20].

The oxidation pond, located on the southern boundary of the University along Old Ede road, was chosen because of the availability of uncased dug pits with depths ranging from 5.0-20.0 m below ground level [22] inside which frogs from the oxidation ponds fall. Since they are unable to get out, they could be easily captured. An oxidation sewage-disposal method is used at the University campus [22] where liquid wastes are released into the ponds daily since 1967. There are two ponds designed to operate in parallel and alternately, so that when pond I is put to function (usually for one week) pond II is at rest and vice versa. Wastewater and sludge are retained in the ponds for about two weeks during which bacteria, algae, fungi, micro- and macro-organisms are allowed to act on them in the process of biodegradation. Effluents from the ponds are discharged into a receiving stream close by that eventually link up with Opa river having a number of tributaries [23].

\section{Methods}

A bucket (20-liter capacity) was used to collect water from bodies of water in which frogs reside with a rope attached, which was used to let the bucket down into the water body. Fishing net (Mesh size $2.5 \mathrm{~cm}$ ) was then used to trap frogs from inside the bucket before they were brought into the laboratory in a 5-liter capacity tin with perforations for adequate aeration. This was carried out every Wednesday around midday throughout the period of the study between years 2002 and 2007, as frogs were less likely to forage for food at that period of the day. Captured specimens were identified using descriptions by Ohio and Anura [24,25] and later released to their respective habitat following their identification.

\section{Results}

Four species of the family Ranidae - Rana asdpersa, $R$. aurora, $R$. clamitans and $R$. sylvatica were found to be resident in the four locations sampled. Occurrence of each species was found to follow the same trend in all the locations of study with $R$. clamitans being the most abundant, followed by $R$. sylvatica then $R$. adspersa and lastly $R$. aurora. The result of the relative distribution of the four species of Ranidae observed all the study areas is presented in figure 1.

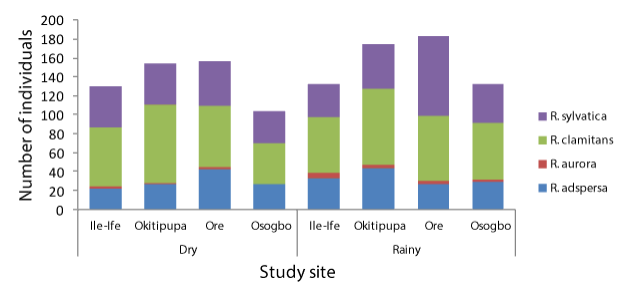

Figure 1: Seasonal distribution (Dry and rainy seasons) of four species of the true frog Rana asdpersa, $R$. aurora, $R$. clamitans and $R$. sylvatica collected from four study sites (Okitipupa, Ore, Osogbo and Ile-Ife) located in the southwestern tropical forests of Nigeria.

In each of the seasons more of $R$. clamitans and $R$. sylvatica were captured than $R$. aurora and $R$. adspersa. The least number of frog species caught in both dry and rainy seasons is $R$. aurora. In all the locations, (Figure $2 \mathrm{a}$ and $2 \mathrm{~b}$ ) more of the female sex were captured 
among each of the species while juveniles were the least in number captured in all the locations among the four species.

Of the one thousand, one hundred and sixty four (1164) individuals caught, $543(46.6 \%)$ of all the frogs caught were captured in the dry season while the remaining 621 (53.4\%) were caught during the rainy season. More frog specimens of all the 4 species were captured in Ore (156 [28.7\%] rainy season; 183 [29.5\%] dry season and Okitipupa (154 [28.4\%] rainy season; 174 [28.0\%] dry season) with the least in Osogbo.
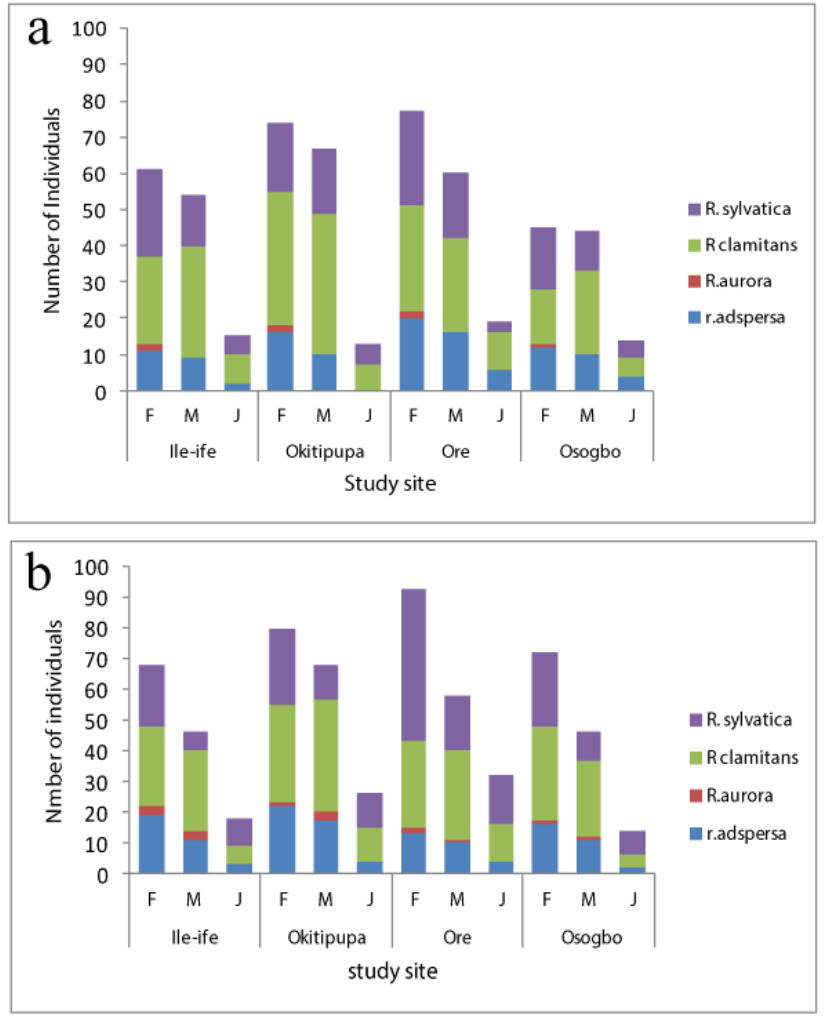

Figure 2: a) sex distribution (M-male; F-female and J-juvenile) of the true frog Rana asdpersa, $R$. aurora, $R$. clamitans and $R$. sylvatica collected from four study sites (Okitipupa, Ore, Osogbo and Ile-Ife) located in the southwestern tropical forests of Nigeria in the dry season. b) sex distribution (M-male; F-female and J-juvenile) of the true frog Rana asdpersa, $R$. aurora, $R$. clamitans and $R$. sylvatica collected from four study sites (Okitipupa, Ore, Osogbo and Ile-Ife) located in the southwestern tropical forests of Nigeria in the rainy season.

\section{Discussion}

Among amphibians, the order Anura constitute the vast majority (88\%) of living species of amphibians and the bulk of their genetic, physiological, ecological, and morphological diversity, which is represented by a total of 5227 species under 32 families and 372 genera are known from the world [2]. This is, to our knowledge, is the first report on seasonal distributions of true frogs, family Ranidae in rainforest fragments in Southwestern Nigeria. True frogs especially $R$. aurora, $R$. adspersa, $R$. clamitans and $R$. sylvatica were found to be resident in the 4 locations sampled for this study with more being found in Ondo State. Although the limited sampling period and number of individuals provide a preliminary estimation of the species, we believe that a general seasonal distribution pattern has been found. Therefore, our current data from locally endangered species, such as ranidaes from rainforest fragments, can be useful in the design of programs on rainforest management and conservation. A similar study in 2007, revealed the total number of 18 species at Ijede and Onidundun. In 2008, the number had reduced to 17 at Ijede and 15 at Onidundun. In the current study, we identified four major species. A human activity is a major factor for the decline in anuran population. The inhabitants were found to have cultivated in and around the vicinities of both study sites, which adversely affected the Ranids population. Farming activity was maintained at Ijede, which further decreased the number. According to Ash [26], for species with complex habitat requirements (such as those using separate breeding or foraging sites), it only takes one crucial habitat feature, such as breeding pond to precipitate the eventual, if not immediate loss of the population [27]. Observed that clear-cut logging is immensely destructive in the short term for both terrestrial and aquatic breeding amphibians. Our current study shows that a major cause of amphibian decline both in diversity and number of individuals when compared to other studies [28] is due mainly to anthropogenic activities, such as the practice of shifting cultivation, which results in the loss of primary/ secondary vegetation in the forest regions, thereby, destroying the once conducive habitat of the Ranids species [29]. Observed that elevated habitat loss and human densities contributed to the decline of 2454 anuran species between 1980 and 2004, compared to 1545 species that were stable and population of 28 species that had increased. The continuous destruction of this rain forest is giving way to the spread of the savanna ecosystem, which does not support a wide diversity of Ranids compare to the forest ecosystem but with forest regrowth, amphibian populations may reestablish themselves in second-growth forest as long as sources of immigrants remain. It is also important to point out that climatic conditions have a great influence on the diversity and distribution of anurans as observed by Schiøtz [30]. Major deforestation could change the local weather pattern such that a given area experiences reduced rainfall [31]. It is also abundantly clear that the Earth's climate is changing in response to anthropogenic greenhouse gas emission. This change has been recognized as a potential problem for amphibian population and can cause potential shift in geographical range [32]. Also pertaining to seasonal conditions, we observed that ranids thrive in conditions where there is higher rainfall, more humid conditions. The highest number of species was recorded at Okitipupa followed by Ore both in the forest with high annual rainfall region, and lowest number recorded at Oshogbo with tall grass of derived savanna like region. This suggests that there are probably higher numbers of species in the forest than in the savanna, which signifies a non-even number of ranid species and individuals inhabiting the different ecosystems, which is influenced mainly by climatic conditions. It is possible that higher rainfall, more humid conditions that are available during the rainy season may have contributed to their high abundance during the rainy season. However, during the dry season these conditions are not available, thereby, significantly reducing their number [33] has observed similar trend in the forest swamp of the River Niger delta in southeastern Nigeria, greater number of anuran species and individuals were captured in the rainy season than the dry season. During the dry season some Ranids move away from temporary pools of water that would have dried and become restricted to large and permanent bodies of water; for example, $R$. clamitans and $R$. sylvatica. Some 
hibernate under leaves of the forest floor, under fallen trees or dig holes ( $R$. aurora and $R$. adspersa) and were difficult to be caught by our sampling technique, reflecting their low numbers caught in this study.

The importance of biomonitoring cannot be over emphasize especially in this present state of amphibian decline and climate change. Amphibians are sensitive to and respond strongly to changes and variability in air and water temperatures, precipitation and hydroperiods of their environment [34]. Global and regional climate change models predict climate warming and increased variability in the timing and type of precipitation [35]. As temperature warms and the availability of water in aquatic habitats becomes more variable, amphibians are likely to experience lower rates of survival [36]. For future biomonitoring plans coupled with statistical and modeling procedures, there is great possibility to advance the phenomenon of conservation in Nigeria, which is a major responsibility of man himself.

\section{References}

1. http://www.iucn.org/about/work/programmes/species/our_work/ the_iucn_red_list/review_11012012_1607/.

2. Frost DR, Grant T, Faivovich JN, Bain RH, Haas A, et al. (2006) The Amphibian Tree of Life. Bulletin of the American Museum of Natural History 297: 370.

3. Hopkins WA (2007) Amphibians as models for studying environmental change. ILAR J 48: 270-277.

4. Muths E, Stephen Corn P, Pessier AP, Earl Green D (2003) Evidence for disease-related amphibian decline in Colorado. Biological Conservation 110: 357-365.

5. http://www.cdc.gov/NCIDOD/eid/vol10no12/03-0804.html.

6. Blaustein AR, Bancroft BA (2007) Amphibian population declines: evolutionary considerations. BioScience 57: 437-444.

7. Pounds JA, Bustamante MR, Coloma LA, Consuegra JA, Fogden MP, et al. (2006) Widespread amphibian extinctions from epidemic disease driven by global warming. Nature 439: 161-167.

8. Duellman WE, Trueb L (1986) Biology of Amphibians. Copeia 2: 549-553.

9. Baillie JEM, Hilton Taylor C, Stuart S (2004) IUCN Red List of Threatened Species: A global species assessment. In IUCN. Gland and Cambridge.

10. Lips KR, Brem F, Brenes R, Reeve JD, Alford RA, et al. (2006) Emerging infectious disease and the loss of biodiversity in a Neotropical amphibian community. Proceedings of the National Academy of Sciences USA 103: 3165-3170.

11. Blaustein AR, Wake DB (1990) Declining Amphibian Populations: A Global Phenomenon. Trends in Ecology and Evolution 5: 203-204.

12. Stuart SN, Chanson JS, Cox NA, Young BE, Rodrigues AS, et al. (2004) Status and trends of amphibian declines and extinctions worldwide. Science 306: 1783-1786.

13. Bossuyt F, Brown RM, Hillis DH, Cannatella DC, Milinkovitch MC (2006) Phylogeny and biogeography of a cosmopolitan frog radiation: Late Cretaceous diversification resulted in continent-scale endemism in the family Ranidae. Systematic Biology 55: 579-594.

14. http://research.amnh.org/herpetology/amphibia/index.php.

15. Chanda SK (2002) Hand book Indian amphibians. Zoological Survey of India: 335.
16. Gazetteer (1965) Federal Republic of Nigeria, Western Nigeria and Municipality of Lagos, Eastern Nigeria. In Federal Survey, Lagos: 2.

17. Oguntoyinbo JS, Areola O, Filani MO (1978) A Geography of Nigerian development. Ibadan: Heinemann Educational Books, Nigeria: 429.

18. Keay RWJ (1959) An outline of Nigeria vegetation. Lagos: Federal Government Printer.

19. Olufowose SO (1985) A study of Anthropophilic female simulidae (Diptera) at Owode Village near Osogbo, Oyo State Thesis. University of Ife, Zoology enDepartmt.

20. Akinpelu AI (1992) Studies on the reproductive activities of three Estrildine Birds (family: Estildidae) in Ile-Ife, Nigeria. Dissertation. Obafemi Awolowo University, Department of Zoology.

21. Fayenuwo JO, Halstead LB (1974) Breeding cycle of straw-colored fruit bat, Eidolon helvum, at Ile-Ife, Nigeria. J Mammal 55: 453-454.

22. Adepelumi AA, Ako BD, Ajayi TR (2001) Groundwater contamination in the basement complex area of Ile-Ife, Southwestern Nigeria: A case study using the electrical resistivity geophysical method. Hydrogeology 9: 611-622.

23. Akinpelu AI (2006) Birds of the sewage stabilization ponds at Obafemi Awolowo University, Ile-Ife, Nigeria. Journal of science and Technology 26: 56-65.

24. http://www.cmnh.orgcollections/vertzoo/frogs/frogs.html.

25. http://animaldiversity.org/site/accounts/information/Anura.html.

26. Ash AN (1997) Disappearance and return of plethodontid salamanders to clearcut plots in the southern Blue Ridge Mountains. Conservation Biology11: 983-989.

27. Dupuis LA (1997) Effects of Logging on Terrestrial Amphibians of Coastal British Columbia. In Amphibians in Decline: Canadian Studies of a Global Problem. Her petological Conservation 1: 185-190.

28. Onadeko AB, Rödel MO, Egonmwan RI, Saliu JK (2010) Herpetological surveys of south-western and south-eastern regions of Nigeria. The Zoologist 8: 34-43.

29. Sodhi NS, Acciaioli A, Erb M, Tan AK (2008) Biodiversity and human livelihoods in protected areas: case studies from the Malay Archipelago. Cambridge: Cambridge University Press.

30. Schiøtz A (1963) The amphibians of Nigeria. Videnskabelige Meddelelser fra Dansk Naturhistorisk Forening. i Kjøbenhavn 125: 1-92.

31. Lannoo MJ (2005) Amphibian Declines: The Conservation Status of U.S. Amphibians. California: University of California Press, Berkeley.

32. Raxworthy CJ, Pearson RG, Rabibisoa N, Rakotondrazafy AM, Ramanamanjato JB, (2008) Extinction vulnerability of tropical montane endemism from warming and upslope displacement: a preliminary appraisal for the highest massif in Madagascar. Global Change Biology 14: $1-18$

33. Akani GC, Politano E, Luiselli L (2003) Amphibians recorded in forest swamp areas of the River Niger Delta (south eastern Nigeria), and the effects of habitat alteration from oil industry development on species richness and diversity. Applied Herpetology 2: 1-22.

34. Carey C, Alexander MA (2003) Climate change and amphibian declines: is there a link? Diversity and Distributions 9: 111-121.

35. Walther GR, Post E, Convey P, Menzel A, Parmesan C, et al. (2002) Ecological responses to recent climate change. Nature 416: 389-395.

36. Gibbons JW, Scott DE, Ryan TJ, Buhlmann KA, Tuberville TD, et al. (2000) The Global Decline of Reptiles, Déjà Vu Amphibians. BioScience 50: 653-666 